\title{
PRAKTEK TATA KELOLA DAN KEPEMILIKAN INSTITUSIONAL: BUKTI EMPIRIS DARI SEKTOR INDUSTRI PERBANKAN
}

\author{
Perminas Pangeran dan Deresti Salaunaung \\ Fakultas Bisnis Universitas Kristen Duta Wacana \\ Email: perminas_pangeran@yahoo.com
}

\begin{abstract}
The purpose of this study is to examine the impact of corporate governance practice on institutional ownership at the banking company in Indonesia. The research is carried by looking at the score of corporate governance on institutional ownership. This study was conducted on 26 banks listed on the Indonesia Stock Exchange.The results showed that corporate governance practices have a positive influence on institutional ownership. The results of this study indicate that institutional investors tend to hold shares of companies with good corporate governance and support the efforts of Bank Indonesia in improving governance practices in the banking sector.
\end{abstract}

Keyword: Corporate Governance Practice; Institutional Ownership

\begin{abstract}
Abstrak: Tujuan dari penelitian ini adalah menguji pengaruh praktek tata kelola perusahaan terhadap kepemilikan institusional pada perusahaan perbankan di Indonesia. Pengujian dilakukan dengan menggunakan skor tata kelola perusahaan terhadap kepemilikan institusional. Penelitian ini dilakukan terhadap 26 bank yang terdaftar di Bursa Efek Indonesia (BEI). Hasil penelitian menunjukkan bahwa praktek tata kelola perusahaan memiliki pengaruh positif terhadap kepemilikan institusional. Hasil penelitian ini mengindikasikan bahwa investor institusional cenderung memegang saham perusahaan dengan tata kelola yang baik dan mendukung usaha Bank Indonesia dalam meningkatkan praktek tata keloladi sektor perbankan.
\end{abstract}

Kata kunci: Praktek Tata Kelola Perusahaan; Kepemilikan Institusional

\section{PENDAHULUAN}

Di Negara Indonesia, isu mengenai good corporate governance (GCG) mengemuka setelah Indonesia mengalami krisis yang berkepanjangan sejak tahun 1998. GCG pertama kali dikenalkan di Indonesia oleh IMF (International Monetary Funds) dalam rangka pemulihan krisis yang melanda Asia timur pada waktu itu, yang juga berdampak besar pada Indonesia. Salah satu penyebab krisis adalah tidak adanya good corporate governance di dalam pengelolaan perusahaan. Dalam kajian yang dilakukan olehBoozAllen \& Hamilton (2008) seperti dikutipkan oleh Bangun dan Jeffry (2008), indeks good corporate governance Indonesia adalah yang paling rendah dengan skor $(2,88)$, jauh dibawah Singapura $(8,93)$, Malaysia $(7,72)$, dan Thailand $(4,89)$. Rendahnya kualitas GCG ditengarai menjadi kejatuhan perusahaan-perusahaan tersebut. Kajian tersebut didukung oleh penelitian yang dilakukan oleh McKinsey (1999) yang meneliti tentang praktek good corporate governance pada perusahaan-perusahaan di Indonesia. Contoh kasus buruknya penerapan good corporate governance dalam industri perbankan di Indonesia dapat dilihat pada kasus Bank Century yang sekarang berganti nama menjadi Bank Mutiara, dimana bank tersebut harus diambil alih oleh Lembaga Penjamin Simpanan (LPS) dan ditetapkan 
sebagai bank gagal pada tahun 2008 akibat banyaknya kredit bermasalah yang dimiliki bank tersebut. Praktek tata kelola perusahaan yang baik dalam perusahaan memainkan peran penting dalam mengarahkan dan mengelola perusahaan. GCG diperlukan karena adanya agency problem yang disebabkan oleh pemisahan kepemilikan sumber daya dan pengelolaan sumber daya (Jensen dan Meckling 1976). Agency problem atau konflik kepentingan antara prinsipal dan agen didefinisikan sebagai berbagai perilaku agen (misalnya, manajer) yang tidak sesuai dengan kepentingan prinsipal (misalnya, pemegang saham).GCG merupakan salah satu mekanisme untuk meminimalkan konflik kepentingan antara agen dan prinsipal.

Di Indonesia, regulator di sektor perbankan adalahBank sentral, yaitu Bank Indonesia dan didukung oleh pemerintah dalam mengelola stabilitas ekonomi dan keuangan bangsa. Berdasarkan peraturan Bank Indonesia Nomor 8/12/PBI/2006 tentang Perubahan atas Peraturan Bank Indonesia Nomor 8/4/PBI/2006 tentang Pelaksanaan Good Corporate Governance bagi Bank Umum yang menjadi dasar hukum Good Corporate Governance dalam sektor perbankan. Peraturan Bank Indonesia mewajibkan perbankan untuk melaporkan praktek tata kelola perusahaan mereka dalam bentuk self-assessment working paper GCG.Formulir ini terdiri dari skor komposit yang menggabungkan semua penilaian pada CG di bank. Pelaporanself-assessmentdari praktek tata kelola perusahaan memiliki tujuan meningkatkan transparansi di sektor perbankan.Self-assessment ini diharapkan dapat memenuhi tujuan dari regulator untuk meningkatkan kinerja sektor perbankan melalui perbaikan dan pelaksanaan GCG.

Penelitian yang ada, Utamadan Musa (2011) lebih menghubungkan praktek tata kelolaterhadap kinerja bank di Indonesia.Hasil penelitian mereka menunjukkan bahwapraktek tata kelolaberpengaruh terhadap kinerja bank di Indonesia. Namun sebaliknya, kinerja bank tidak memiliki pengaruh terhadap praktek tata kelolanya.Penelitiannya juga menemukan bahwa bank pemerintah daerah memiliki kinerja lebih baik dibandingkan bank swasta nasional.Hasil penelitian ini mendukung usaha Bank Indonesia dalam meningkatkan Praktek tata kelola di dalam sektor perbankan, untuk memperkuat modal dasar bank dan kebijakan Bank Indonesia dalam mendorong bank untuk melakukan merger dan menjadi semakin besar.

Meskipun demikian, dalam konteks Indonesia, penelitian tentang pengaruh praktik tata kelola terhadap pemegang saham institusional masih belum dikaji lebih dalam.Hamdan dan Al-Sartawi (2013) menjelaskan bahwa investor institusionalcenderung ke saham perusahaan dengan struktur tata kelola yang baik.McKinsey dan Co (2002) melakukan survei yang hasilnya juga menunjukkan bahwa para investor cenderung menghindari perusahaan-perusahaan dengan predikat buruk dalam tata kelola perusahaan. Perhatian yang diberikan investor terhadap good corporate governance (GCG) sama besarnya dengan perhatian terhadap kinerja keuangan perusahaan. Para investor yakin bahwa perusahaan yang menerapkan praktek GCG akan meningkatkan nilai perusahaan diantaranya kinerja keuangan perusahaan, mengurangi resiko yang merugikan akibat tindakan pengelola yang cenderung menguntungkan diri sendiri dan meningkatkan harga saham perusahaan dalam jangka panjang seperti riset yang dilakukan McKinsey (2002) menyatakan bahwa 51\% investor menuntut adanya transparansi sebagai acuan dalam melakukan pembelian saham perusahaan oleh investor institusional. Dengan kata lain corporate governance akan menciptakan kinerja perusahaan yang baik dan meningkatkan kepercayaan investor terhadap kinerja perusahaan. 
Selain itu, Badrinath, Kale, dan Ryan (1996), Falkenstein (1996), dan Huang (2009) menunjukkan bahwa investor institusional lebih memilih saham-saham yang memiliki likuiditas pasar yang lebih tinggi dan volatilitas return yang lebih rendah. Studi lain menunjukkan bahwa investor institusional lebih memilih saham perusahaan dengan pengungkapan yang lebih baik (Bushee dan Noe, 2000), saham perusahaan yang lebih besar (Gompers dan Metrick, 2001), saham perusahaan yang membayar dividen tunai atau pembelian kembali saham (Grinstein dan Michaely, 2005), dan saham perusahaan dengan kinerja manajerial yang lebih baik (Parrino, Sias, dan Starks, 2003).

Chung dan Zhang (2011), menguji hubungan antara tata kelola perusahaan dan kepemilikan institusional. Hasil penelitian mereka menunjukkan bahwa sebagian kecil saham perusahaan yang dipegang oleh investor institusional meningkat dengan kualitas struktur tata kelolanya. Dalam hal yang sama, mereka menunjukkan bahwa proporsi institusi yang memegang saham suatu perusahaan meningkat dengan kualitas tata kelola perusahaan.

Berdasarkan uraian diatas, investor insitusional cenderung lebih memilih saham perusahaan yang memiliki tata kelola perusahaan yang baik daripada investor individu karena perusahaan dengan tata kelola yang baik cenderung membutuhkan lebih sedikit pemantauan dan memiliki likuiditas pasar saham yang lebih tinggi. Oleh karensa itu, penelitian ini akanmenguji pengaruh praktek corporate governance (CG) terhadap kepemilikan institusional pada perusahaan perbankan yang terdaftar di Bursa Efek Indonesia. Dengan praktekcorporate governance ditentukan oleh indeks komposit Corporate Governance Bank sesuai dengan Peraturan Bank Indonesia Nomor 8/12/PBI/2006 tentang Perubahan atas Peraturan Bank Indonesia Nomor 8/4/PBI/2006 tentang Pelaksanaan Good Corporate Governance.

Penelitian ini dilakukan berbeda dengan penelitian sebelumnya, pada penelitian ini dilakukan pada sampel perusahaan perbankan yang terdaftar di Bursa Efek Indonesia (BEI) pada tahun 2011-2013.Selain itu, penelitian ini berpedoman pada Peraturan Bank Indonesia Nomor 8/12/PBI/2006 tentang Perubahan atas Peraturan Bank Indonesia Nomor 8/4/PBI/2006 tentang Pelaksanaan Good Corporate Governance.Pada penelitian ini, menekan pada dimensi praktek Corporate Governance dilihat dari indeks komposit Corporate Governance Bank sesuai dengan Peraturan Bank Indonesia Nomor 8/12/PBI/2006 tentang Perubahan atas Peraturan Bank Indonesia Nomor 8/4/PBI/2006 tentang Pelaksanaan Good Corporate Governance.

Penelitian ini diharapkan dapat melengkapi penelitian-penelitian terdahulu tentang praktekcorporate governance (CG) dan kepemilikan institusional dan dapat menambah referensi atau pengetahuan tentang tata kelola perusahaan dan investor institusional serta dapat dikembangkan kembali menjadi suatu karya penelitian selanjutnya.Dengan adanya penelitian ini dapat menjadi suatu masukan bagi perusahaan untuk menerapkan corporate governance yang baik bagi perusahaan agar dapat meningkatkan nilai perusahaan serta dapat menarik minat investor ke saham perusahaan.

\section{KAJIAN TEORI}

Teori Keagenan. Dalam rangka memahami konsep Good Corporate Governance (GCG), maka digunakanlah dasar perspektif hubungan keagenan. Hubungan keagenan merupakan hubungan antara dua pihak dimana salah satu pihak menjadi agen dan pihak lain bertindak sebagai principal. Hubungan keagenan muncul ketika satu orang atau lebih (principal) 
mempekerjakan orang lain (agency) untuk memberikan suatu jasa dan kemudian mendelegasikan wewenang pengambilan keputusan kepada agen tersebut.

Eisenhardt (1989) dikutip dalam Isnanta (2008) menggunakan tiga asumsi sifat dasar manusia guna menjelaskan tentang teori agensi yaitu: (1) manusia pada umumnya mementingkan diri sendiri (self interest), (2) manusia memiliki daya pikir terbatas mengenai persepsi masa mendatang (bounded rationality), dan (3) manusia selalu menghindari risiko (risk averse). Berdasarkan asumsi sifat dasar manusia tersebut, manajer sebagai manusia kemungkinan besar akan bertindak berdasarkan sifat opportunistic, yaitu mengutamakan kepentingan pribadinya.

Jensen dan Meckling (1976) menjelaskan adanya konflik kepentingan dalam hubungan keagenan.Terjadinya konflik kepentingan antara pemilik dan agen karena kemungkinan agen bertindak tidak sesuai dengan kepentingan principal, sehingga memicu biaya keagenan (agency cost).Teori Agensi mampu menjelaskan potensi konflik kepentingan diantara berbagai pihak yang berkepentingan dalam perusahaan tersebut.Konflik kepentingan ini terjadi dikarenakan perbedaan tujuan dari masing-masing pihak berdasarkan posisi dan kepentingannya terhadap perusahaan (Ibrahim, 2007).Sebagai agen, manajer bertanggung jawab secara moral untuk mengoptimalkan keuntungan para pemilik, namun demikian manajer juga menginginkan untuk selalu memperoleh kompensasi sesuai dengan kontrak.Dengan demikian terdapat dua kepentingan yang berbeda di dalam perusahaan dimana masing-masing pihak berusaha untuk mencapai atau mempertahankan tingkat kemakmuaran yang dikehendaki (Ali, 2002 dalam Isnanta, 2008).

Selain itu Teori Agensi juga menjelaskan mengenai masalah asimetris informasi. Manajer sebagai pengelola perusahaan lebih banyak mengetahui informasi internal dan prospek perusahaan di masa yang akan datang dibandingkan pemilik (pemegang saham). Oleh karena itu sebagai pengelola, manajer diwajibkan memberi sinyal mengenai kondisi perusahaan kepada pemilik.Akan tetapi informasi yang disampaikan terkadang diterima tidak sesuai dengan kondisi perusahaan sebenarnya.Kondisi ini dikenal sebagai informasi yang tidak simetris atau asimetri informasi.

Asimetri informasi antara manajemen dengan pemilik dapat memberikan kesempatan kepada manajer untuk melakukan tindakan oportunis seperti manajemen laba mengenai kinerja ekonomi perusahaan sehingga dapat merugikan pemilik (pemegang saham). Manajer akan berusaha melakukan hal tersebut untuk memaksimalkan kepentingan pribadinya tanpa persetujuan pemilik atau pemegang saham. Penelitian Richardson (1998) dalamUjiyantho dan Pramuka (2007) menunjukan adanya hubungan positif antara asimetri informasi dengan manajemen laba. Dalam hal ini berarti apabila manajer memiliki informasi yang lebih banyak dibandingkan dengan pemegang saham maka kecenderungan manajer untuk berbuat curang dengan Praktek manajemen laba demi kepentingan pribadi akan semakin tinggi.

Dengan adanya masalah agensi yang disebabkan karena konflik kepentingan dan asimetri informasi ini, maka perusahaan harus menanggung biaya keagenan.Jensen dan Meckling (1976) menjelaskan biaya keagenan dalam tiga jenis yaitu: (1) Biaya Monitoring, merupakan biaya yang dikeluarkan untuk melakukan pengawasan terhadap aktivitas-aktivitas yang dilakukan oleh agen; (2) Biaya pengikatan (bonding cost), merupakan biaya untuk menjamin bahwa agen tidak akan bertindak merugikan principal, atau dengan kata lain untuk meyakinkan agen, bahwa principal akan memberikan kompensasi jika agen benar-benar melakukan tindakan tersebut; (3) Biaya kerugian 
residual, merupakan nilai uang yang ekuivalen dengan pengurangan kemakmuran yang dialami oleh principal akibat dari perbedaan kepentingan.

Teori Agensi juga menyatakan bahwa konflik kepentingan antara agen dan principal dapat dikurangi dengan mekanisme pengawasan yang dapat menyelaraskan berbagai kepentingan yang ada dalam perusahaan (Ibrahim, 2007).Mekanisme pengawasan yang dimaksud dalam teori agensi dapat dilakukan dengan mekanisme good corporate governance (GCG).GCG sebagai suatu sistem yang mengatur dan mengendalikan perusahaan diharapkan dapat memberikan kepercayaan terhadap manajemen dalam mengelola kekayaan pemilik (pemegang saham), sehingga dapat meminimalkan konflik kepentingan dan meminimumkan biaya keagenan.Herawaty (2008) juga menyatakan bahwa good corporate governance (GCG) menghasilkan berbagai mekanisme yang bertujuan meyakinkan bahwa tindakan manajemen selaras dengan kepentingan pemegang saham (terutama minority interest).

Konsep GCG berkaitan dengan bagaimana para pemilik (pemegang saham) yakin bahwa manajer akan memberikan keuntungan bagi mereka, yakni bahwa manajer tidak akan melakukan kecurangan-kecurangan yang akan merugikan para pemegang saham. Dengan kata lain dengan penerapan good corporate covernance diharapkan dapat berfungsi untuk menekan atau menurunkan biaya keagenan (agency cost).

Konsep GoodCorporate Governance (GCG). Menurut Peraturan Bank Indonesia Nomor 8/14/PBI/2006, Good Corporate Governance (GCG) didefinisikan sebagai suatu tata kelola bank yang menerapkan prinsip-prinsip keterbukaan (transparency), akuntabilitas (accountability), pertanggungjawaban (responsibility), independensi (independency), serta kewajaran (fairness). GCG juga dapat diartikan sebagai suatu proses dan struktur yang digunakan untuk meningkatkan keberhasilan usaha dan akuntabilitas perusahaan yang bertujuan untuk meningkatkan nilai perusahaan dalam jangka panjang dengan memperhatikan kepentingan pemilik serta berlandaskan peraturan dan prinsip yang sesuai dengan perundang-undangan GCG.

Peraturan Bank Indonesia Nomor 8/14/PBI/2006 menegaskan tentang perlunya peningkatan kualitas pelaksanaan karena besarnya risiko dan tantangan yang dihadapi oleh bank dari lingkungan internal maupun eksternal. Dalam menerapkan prinsip tata kelola perusahaan yang baik diperlukan suatu struktur yang kuat yang mampu bertindak sebagai panutan dan motor penggerak agar penerapan GCG dapat berjalan secara optimal.

Beberapa konsep tentang corporate governance antara lain yang dikemukakan oleh Shleifer and Vishny (1997) yang menyatakan corporate governance berkaitan dengan cara atau mekanisme untuk meyakinkan para pemilik modal dalam memperoleh return yang sesuai dengan investasi yang telah ditanam. Corporate governance merujuk pada kerangka aturan dan peraturan yang memungkinkan stakeholders untuk membuat perusahaan memaksimalkan nilai dan untuk memperoleh return. Selain itu corporate governance merupakan alat untuk menjamin direksi dan manajer (atau insider) agar bertindak yang terbaik untuk kepentingan investor luar (kreditur atau shareholder.

Sehubungan dengan penerapan good corporate governance, Bank Indonesia telah mengeluarkan Peraturan Bank Indonesia Nomor 8/4/PBI/2006 tanggal 30 Januari 2006 tentang Pelaksanaan Good Corporate Governance Bagi Bank Umum sebagaimana telah diubah dengan Peraturan Bank Indonesia Nomor 8/14/PBI/2006 tanggal 6 Oktober 2006 serta Surat Edaran Bank Indonesia (SEBI) No. 9/12/DPNP tanggal 30 Mei 2007. Adapun aturan umum yang tertuang dalam Surat Edaran Bank Indonesia (SEBI) No. 9/12/DPNP antara lain: 
Pertama, pelaksanaan Good Corporate Governance pada industri perbankan harus senantiasa berlandaskan pada lima prinsip dasar.

Pertama, transparansi, yaitu keterbukaan dalam mengemukakan informasi yang material dan relevan serta keterbukaan dalam proses pengambilan keputusan. Kedua, akuntabilitas yaitu kejelasan fungsi dan pelaksanaan pertanggungjawaban organ Bank sehingga pengelolaannya berjalan secara efektif.Ketiga, pertanggungjawaban yaitu kesesuaian pengelolaan Bank dengan peraturan perundang-undangan yang berlaku dan prinsip-prinsip pengelolaan Bank yang sehat.Keempat, independensi yaitu pengelolaan Bank secara profesional tanpa pengaruh/tekanan dari pihak manapun. Kelima, kewajaran yaitu keadilan dan kesetaraan dalam memenuhi hak-hak stakeholders yang timbul berdasarkan perjanjian dan peraturan perundang-undangan yang berlaku. Dalam rangka menerapkan kelima prinsip dasar tersebut di atas, Bank harus berpedoman pada berbagai ketentuan dan peraturan perundang undangan yang berlaku yang terkait dengan pelaksanaan Good Corporate Governance.

Kedua, Bank wajib melaksanakan prinsip-prinsip Good Corporate Governance dalam setiap kegiatan usahanya pada seluruh tingkatan atau jenjang organisasi.Yang dimaksud dengan seluruh tingkatan atau jenjang organisasi adalah seluruh pengurus dan karyawan Bank mulai dari Dewan Komisaris dan Direksi sampai dengan pegawai tingkat pelaksana. Ketiga, dalam pelaksanaan Good Corporate Governance tersebut, diperlukan keberadaan Komisaris Independen dan Pihak Independen. Keberadaan pihak-pihak independen tersebut, diharapkan dapat menciptakan check and balance, menghindari benturan kepentingan dalam pelaksanaan tugasnya serta melindungi kepentingan stakeholders khususnya pemilik dana dan pemegang saham minoritas. Untuk mendukung independensi dalam pelaksanaan tugas, perlu kejelasan pengaturan mengenai masa tunggu (cooling off) bagi pihak-pihak yang akan menjadi pihak-pihak independen.

Keempat, dalam mengimplementasikan prinsip transparansi sebagaimana termaksud di atas, Bank diwajibkan untuk menyampaikan Laporan Pelaksanaan Good Coporate Governance. Keberadaan laporan dimaksud, diperlukan untuk mengedukasi serta meningkatkan check and balance stakeholders Bank dan persaingan melalui mekanisme pasar. Kelima, dalam upaya perbaikan dan peningkatan kualitas pelaksanaan Good Corporate Governance, Bank diwajibkan secara berkala melakukan self assessment secara komprehensif terhadap kecukupan pelaksanaan Good Corporate Governance, sehingga apabila masih terdapat kekurangan dalam pengimplementasiannya, Bank dapat segera menetapkan rencana tindak yang meliputi tindakan korektif yang diperlukan.

Untuk mewujudkan terciptanya GCG, prinsip-prinsip tersebut harus dapat dicapai oleh perusahaan, dengan adanya kerja sama yang baik dari berbagai pihak baik di dalam maupun di luar perusahaan. Dewan komisaris, Dewan Direksi, Komite Audit dan karyawan merupakan organ-organ perusahaan yang memegang peranan kunci pelaksanaan GCG.

Priambodo dan Suprayitno (2007) menjelaskan manfaat-manfaat dari penerapan goodcorporate governance dalam suatu perusahaan. Pertama, mengurangi agency cost, biaya yang timbul karena penyalahgunaan wewenang (wrong doing), ataupun berupa biaya pengawasan yang timbul untuk mencegah terjadinya suatu masalah (Daniri, 2005).Kedua, meningkatkan nilai saham perusahaan, sehingga dapat meningkatkan citra perusahaan dimata publik dalam jangka waktu yang lama (Daniri, 2005).Ketiga, melindungi hak dan kepentingan pemegang saham (Sutojo dan Aldridge, 2005).Keempat, meningkatkan efisiensi dan efektivitas kerja dewan pengurus atau manajemen puncak dan 
manajemen perusahaan, sekaligus meningkatkan mutu hubungan manajemen puncak dengan manajemen senior perusahaan (Sutojo dan Aldridge, 2005).

Dimensi PraktekCorporate Governance. Sehubungan dengan telah dikeluarkannya Peraturan Bank Indonesia Nomor 8/4/PBI/2006 tanggal 30 Januari 2006 tentang Pelaksanaan Good Corporate Governance bagi Bank Umum (Lembaran Negara Republik Indonesia Tahun 2006 Nomor 6, Tambahan Lembaran Negara Republik Indonesia Nomor 4600) dan Peraturan Bank Indonesia Nomor 8/14/PBI/2006 tanggal 5 Oktober 2006 tentang Perubahan atas Peraturan Bank Indonesia Nomor 8/4/PBI/2006 tentang Pelaksanaan Good Corporate Governance bagi Bank Umum (Lembaran Negara Republik Indonesia Tahun 2006 Nomor 71, Tambahan Lembaran Negara Republik Indonesia Nomor 4640), maka perlu diatur ketentuan pelaksanaan dalam suatu Surat Edaran Bank Indonesia dengan pokok-pokok ketentuan sebagai dijelaskan sebagai berikut.

Dewan Komisaris Independen. Dalam Peraturan Bank Indonesia Nomor 8/12/PBI/2006 tentang Perubahan atas Peraturan Bank Indonesia Nomor 8/4/PBI/2006 tentang Pelaksanaan Good Corporate Governance proporsi dewan komisaris independen ditetapkan paling kurang 50\% (lima puluh persen) dari jumlah anggota dewan komisaris. Komisaris Independen adalah anggota Dewan Komisaris yang tidak memiliki hubungan keuangan, kepengurusan, kepemilikan saham, dan/atau hubungan keluarga dengan anggota Dewan Komisaris lainnya, Direksi dan/atau Pemegang Saham Pengendali atau hubungan dengan Bank, yang dapat mempengaruhi kemampuannya untuk bertindak independen.

Komisaris independen diukur dengan proporsi antara jumlah komisaris independen dengan seluruh total anggota dewan komisaris perusahaan. Penelitian Evans, dkk (2002) melaporkan hasil bahwa tidak terdapat hubungan positif yang secara statistik signifikan antara rasio komisaris independen dengan kinerja perusahaan. Penelitian Fuerst dan Kang (2004) menguji corporate governance dan kinerja operasi, menunjukan adanya hubungan positif antara komisaris independen dan kinerja perusahaan.Beasley (1996) menguji hubungan antara proporsi dewan komisaris dengan kecurangan pelaporan keuangan.Dengan membandingkan perusahaan yang melakukan kecurangan dengan perusahaan yang tidak melakukan kecurangan, mereka menemukan bahwa perusahaan yang melakukan kecurangan memiliki presentase dewan komisaris eksternal secara signifikan lebih rendah dibandingkan dengan perusahan yang tidak melakukan kecurangan.

Berdasarkan Pedoman Good Corporate Governance, komposisi atau jumlah Komisaris Independen tidak ditentukan dalam jumlah tertentu namun demikian jumlah atau komposisi komisaris independen harus dapat menjamin agar mekanisme pengawasan berjalan secara efektif dan sesuai dengan peraturan perundang-undangan. Adapun kriteria yang ditetapkan yaitu salah satu dari Komisaris Independen harus mempunyai latar belakang akuntasi atau keuangan. Meskipun Pedoman Good Corporate Governance tidak menentukan jumlah Komisaris Independen, dalam Peraturan Bapepam-LK, Emiten atau Perusahaan wajib memiliki sekurang-kurangnya satu orang komisaris independen sedangkan di Peraturan Bank Indonesia mewajibkan paling kurang 50\% dari jumlah anggota dewan komisaris adalah Komisaris Independen.

Dewan komisaris yang independen secara umum mempunyai pengawasan yang lebih baik terhadap manajemen, sehingga mempengaruhi kemungkinan kecurangan dalam menyajikan laporan keuangan yang dilakukan oleh manajer atau dengan kata lain, 
semakin kompeten dewan komisaris maka semakin mengurangi kemungkinan kecurangan dalam pelaporan keuangan.

Dewan komisaris merupakan mekanisme pengendalian intern tertinggi yang bertanggung jawab secara kolektif untuk melakukan pengawasan dan memberikan nasihat kepada Direksi serta memastikan bahwa perusahaan melaksanakan GCG (KNKG, 2006). Berdasarkan Forum Corporate Governance Indonesia (FCGI), Dewan Komisaris merupakan inti tata kelola perusahaan(corporate governance) yang ditugaskan untuk menjamin pelaksanaan strategi perusahaan, mengawasi manajemen dalam mengelola perusahaan serta mewajibkan terlaksananya akuntabilitas.

Beasley (1996) menyarankan bahwa masuknya dewan komisaris yang berasal dari luar perusahaan meningkatkan efektivitas dewan tersebut dalam mengawasi manajemen untuk mencegah kecurangan laporan keuangan. Menurut Egon Zehnder (2000), Dewan Komisaris (merupakan inti dari Corporate Governance) yang ditugaskan untuk mejamin pelaksanaan strategi perusahaan, mengawasi manajemen dalam mengelola perusahaan, serta mewajibkan terlaksananya akuntabilitas. Secara teori dan Praktek, tugas utama dari dewan komisaris adalah melakukan pengawasan terhadap manajemen untuk memastikan bahwa mereka melakukan segala aktivitas dengan kemampuan terbaiknya bagi kepentingan perseroan, serta menanggalkan keputusan yang tidak menguntungkan. Komposisi dewan komisaris merupakan salah satu karakteristik dewan yang berhubungan dengan informasi laba.Melalu perannya dalam menjalankan fungsi pengawasan, komposisi dewan dapat mempengaruhi pihak manajemen dalam menyusun laporan sehingga dapat diperoleh suatu laporan laba yang berkualitas (Boediono, 2005).

Dewan Direksi. Dalam Peraturan Bank Indonesia Nomor 8/12/PBI/2006 tentang Perubahan atas Peraturan Bank Indonesia Nomor 8/4/PBI/2006 tentang Pelaksanaan Good Corporate Governance. Presiden Direktur atau Direktur Utama wajib berasal dari pihak yang independen terhadap Pemegang Saham Pengendali.Independensi Presiden Direktur dapat dipenuhi apabila yang bersangkutan tidak memiliki hubungan keuangan, kepengurusan, kepemilikan saham dan/atau hubungan keluarga dengan Pemegang Saham Pengendali Bank.

Menurut UU No. 40 Tahun 2007 Tentang Perseroan Terbatas Pasal 1 Direksi yaitu suatu organ perseroan yang berwenang dan yang bertanggung jawab penuh dalam kepengurusan Perseroan untuk kepentingan Perseroan, yaitu sesuai dengan maksud dan tujuan Perseroan dan mewakili Perseroan baik di dalam maupun di luar pengadilan yang sesuai dengan ketentuan anggaran dasar.

Fungsi, wewenang, dan tanggung jawab direksi secara tersurat diatur dalam UndangUndang Nomor 40 Tahun 2007 Tentang Perseroan Terbatas. Dalam Undang-Undang dewan direksi mempunyai tugas, diantaranya: 1) memimpin perusahaan dengan menerbitkan kebijakan-kebijakan perusahaan. 2) memilih, menetapkan dan mengawasi tugas karyawan dan kepala bagian (manajer). 3) menyetujui anggaran tahunan perusahaan. 4) menyampaikan laporan kepada pemegang saham atas kinerja perusahaan.

Direksi wajib mengungkapkan kepada pegawai kebijakan Bank yang bersifat strategis di bidang kepegawaian. Yang dimaksud dengan kebijakan yang bersifat strategis di bidang kepegawaian, antara lain kebijakan mengenai sistem recruitment, sistem promosi, sistem remunerasi serta rencana Bank untuk melakukan efisiensi melalui pengurangan pegawai. Pengungkapan tersebut harus dilakukan melalui sarana yang diketahui atau diakses dengan mudah oleh pegawai. 
Direksi dilarang memberikan kuasa umum kepada pihak lain yang mengakibatkan pengalihan tugas dan fungsi Direksi. Pemberian kuasa umum adalah pemberian kuasa kepada satu orang karyawan atau lebih atau orang lain yang mengakibatkan pengalihan tugas, wewenang dan tanggung jawab Direksi secara menyeluruh tanpa batasan ruang lingkup dan waktu.

Segala keputusan Direksi diambil sesuai dengan pedoman dan tata tertib kerja, yang mengikat dan menjadi tanggung jawab seluruh anggota Direksi.Dalam hal terjadi perbedaan pendapat (dissenting opinion), wajib dicantumkan secara jelas dalam risalah rapat Direksi beserta alasan perbedaannya.Terkait dengan hal tersebut, salinan risalah rapat Direksi yang telah ditandatangani oleh seluruh anggota Direksi yang hadir, harus didistribusikan kepada seluruh anggota Direksi.

Komite Audit. Dalam Peraturan Bank Indonesia Nomor 8/12/PBI/2006 tentang Perubahan atas Peraturan Bank Indonesia Nomor 8/4/PBI/2006 tentang Pelaksanaan Good Corporate Governance.Yang dimaksud dengan Pihak Independen bagi anggota Komite adalah pihak di luar Bank yang tidak memiliki hubungan keuangan, kepengurusan, kepemilikan saham dan/atau hubungan keluarga dengan Dewan Komisaris, Direksi dan/atau Pemegang Saham Pengendali atau hubungan dengan Bank, yang dapat mempengaruhi kemampuannya untuk bertindak independen.

Dalam menajalankan tugasnya, Dewan Komisaris dapat membentuk komite-komite yang dapat membantu pelaksanaan tugasnya.Salah satunya adalah Komite Audit, yang memiliki tugas terpisah dalam membantu Dewan Komisaris untuk memenuhi tanggung jawabnya dalam memberikan pengawasan secara menyeluruh (FCGI, 2002). Pada umumnya Komite Audit mempunyai tanggung jawab pada tiga bidang, yaitu pertama, Laporan Keuangan (Financial Reporting), adalah untuk memastikan bahwa laporan keuangan yang dibuat oleh manajemen telah memberikan gambaran yang sebenarnya Kondisi Keuangan, Hasil Usahanya, serta Rencana dan komitmen jangka panjang.

Kedua, Tata Kelola Perusahaan (Corporate Gocernance), adalah untuk memastikan, bahwa perusahaan telah dijalankan sesuai undang-undang dan peraturan yang berlaku, melaksanakan usahanya dengan beretika, melaksanakan pengawasannya secara efektif terhadap benturan kepentingan dan kecurangan yang dilakukan oleh karyawan perusahaan.

Ketiga, Pengawasan Perusahaan (Corporate Control). Tanggung jawab Komite Audit untuk pengawasan perusahaan termasuk di dalamnya pemahaman tentang masalah serta hal-hal yang berpotensi mengandung risiko dan sistem pengendalian intern serta memonitor proses pengawasan yang dilakukan oleh auditor internal. Ruang lingkup audit internal harus meliputi pemeriksaan dan penilaian tentang kecukupan dan efektifitas sistem pengawasan intern.

Dalam Pedoman GCG Indonesia (KNKG, 2006) dijelaskan bahwa, Komite Audit bertugas membantu Dewan Komisaris untuk memastikan bahwa: (1) laporan keuangan disajikan secara wajar sesuai dengan prinsip akuntasi yang berlaku umum, (2) struktur pengendalian internal perusahaan dilaksanakan dengan baik, (3) pelaksanaan audit internal maupun eksternal dilaksanakan sesuai dengan standar audit yang berlaku, dan (4) tindak lanjut temuan hasil audit dilaksanakan oleh manajemen.

Menurut KNKG (2006) Jumlah anggota Komite Audit harus disesuaikan dengan kompleksitas perusahaan dengan tetap memperhatikan efektifitas dalam pengambilan keputusan.Menurut Peraturan Bank Indonesia Nomor Nomor 8/12/PBI/2006 tentang 
Perubahan atas Peraturan Bank Indonesia Nomor 8/4/PBI/2006 tentang Pelaksanaan Good Corporate Governance.Pihak Independen bagi anggota Komite adalah pihak di luar Bank yang tidak memiliki hubungan keuangan, kepengurusan, kepemilikan saham dan/atau hubungan keluarga dengan Dewan Komisaris, Direksi dan/atau Pemegang Saham Pengendali atau hubungan dengan Bank, yang dapat mempengaruhi kemampuannya untuk bertindak independen.

Komite Audit harus terdiri dari individu-individu yang mandiri dan tidak terlibat dengan tugas sehari-hari dari manajemen yang mengelola perusahaan, dan memiliki pengalaman untuk melaksanakan fungsi pengawasan secara efektif.Salah satu dari beberapa alasan utama kemandirian ini adalah untuk memelihara integritas serta pandangan yang objektif dalam laporan serta penyusunan rekomendasi yang diajukan oleh Komite Audit, karena individu yang mandiri cenderung lebih adil dan tidak memihak serta obyektif dalam menangani suatu permasalah (FCGI, 2002). Komite Audit akan bertanggung jawab langsung kepada Dewan Komisaris. Dengan demikian, apabila fungsi dan tanggung jawab Komite Audit dapat dilaksanakan dengan baik, maka hal ini akan mendorong terwujudnya prinsip-prinsip GCG yang akan mendorong perusahan untuk selalu bertanggung jawab kepada kepentingan seluruh stakeholders.

Kepemilikan Institusional (Institutional Ownership). Konsentrasi kepemilikan institusional merupakan saham perusahaan yang dimiliki oleh institusi atau lembaga seperti perusahaan asuransi, perusahaan investasi dan kepemilikan institusi lain. Institusi merupakan sebuah lembaga yang memiliki kepentingan besar terhadap investasi yang dilakukan termasuk investasi saham.Sehingga biasanya institusi menyerahkan tanggungjawab pada divisi tertentu untuk mengelola investasi perusahaan tersebut.Karena institusi memantau secara profesional perkembangan investasinya maka tingkat pengendalian terhadap tindakan manajemen sangat tinggi sehingga potensi keuangan dapat ditekan (Lastanti, 2004). Keberadaan institusi inilah yang mampu menjadi alat monitoring efektif bagi perusahaan.

Kepemilikan institusional memiliki kelebihan antara lain: memiliki profesionalisme dalam menganalisis informasi, sehingga dapat menguji keandalan informasi.Selain itu kemilikan institusional memiliki motivasi yang kuat untuk melaksanakan pengawasan yang lebih ketat atas aktivitas yang terjadi di dalam perusahaan. Kepemilikan saham institusional umumnya mampu mengurangi masalah agensi di dalam perusahaan. Fungsi pengendalian akan semakin efektif apabila pemegang saham memiliki kemampuan dan pengalaman yang baik di bidang bisnis dan keuangan.

Model Teoritis. Chung dan Zhang (2011) menganalisis hubungan antara struktur tata kelola perusahaan dan keputusan pemilihan saham investor institusional. Mereka menduga bahwa investor institusional lebih memilih saham perusahaan yang lebih baik diatur untuk tanggung jawab fidusia, biaya monitoring, dan alasan likuiditas, dan menemukan bukti yang konsisten dengan dugaan tersebut. Secara khusus, mereka menemukan bahwa sebagian kecil dari saham perusahaan yang dipegang oleh investor institusional meningkat dengan dua langkah komprehensif dari kualitas tata kelola perusahaan yang dibangun dari 50 faktor governance. Hasil mereka juga menunjukkan bahwa proporsi institusi yang memegang saham suatu perusahaan meningkat dengan kualitas tata kelola. Mereka melakukan sejumlah pemeriksaan kekokohan dan menunjukkan bahwa hasilutama adalah kuat. 
Hamdan dan Al-Sartawi (2013) menguji hubungan antara tata kelola perusahaan dan kepemilikan institusional. Sampel penelitian berisi 98,5\% dari perusahaan sektor keuangan Kuwait, yang terdaftar di Bursa Efek Kuwait dan yang merupakan 66 Perusahaan selama tahun 2010. Hasil deskriptif mengindikasikan bahwa ada sebuah aplikasi rata-rata, yang secara statistik signifikan terhadap kondisi corporate governance di sektor keuangan Kuwait. Hasil empiris menunjukkan bahwa fraksi saham perusahaan, yang diselenggarakan oleh investor institusional, menurun dengan kualitas struktur tata kelolanya. Hasil ini tidak konsisten dengan dugaan bahwa investor institusional condong ke saham perusahaan dengan struktur tata kelola yang baik.

Utamadan Musa (2011) menguji hubungan timbal-balik antara praktek tata kelola dan kinerja bank umum di Indonesia. Pengujian dilakukan dengan melihat pengaruh dari umur, indikator kecukupan modal, tipe bank terhadap kinerja bank dan selanjutnya dilihat pula pengaruh dari ukuran bank, kepemilikan asing, dan status terdaftar di bursa terhadap Praktek tata kelola bank tersebut. Hasil penelitian menunjukkan bahwa Praktek tata kelola, ukuran bank, dan rasio kecukupan modal memiliki pengaruh positif terhadap kinerja bank di Indonesia.Tetapi, kinerja bank tidak memiliki pengaruh terhadap Praktek tata kelolanya. Studi juga menemukan bahwa bank pemerintah daerah memiliki kinerja lebih baik dibandingkan bank swasta nasional.

Triyono (2014) menganalisis pengaruh kualitas corporate governance, kepemilikan institusional, terhadap kinerja dan risiko. Hasilnya menunjukan bahwa kualitas tata kelola perusahaan dan kepemilikan institusional berpengaruh terhadap kinerja perusahaan.Kepemilikan Institusional adalah kepemilikan saham oleh pemerintah, institusi keuangan, institusi berbadan hukum, institusi luar negeri, dana perwalian dan institusi lainnya pada akhir tahun.

Berdasarkan teori, maka peneliti mengindikasikan praktek corporate governance dalam hal ini dilihat dari skor tata kelola perusahaan sebagai variabel independen, dan kepemilikan institusional sebagai variabel dependen. Adapun model kerangka pemikiran penelitian ini adalah sebagai berikut:

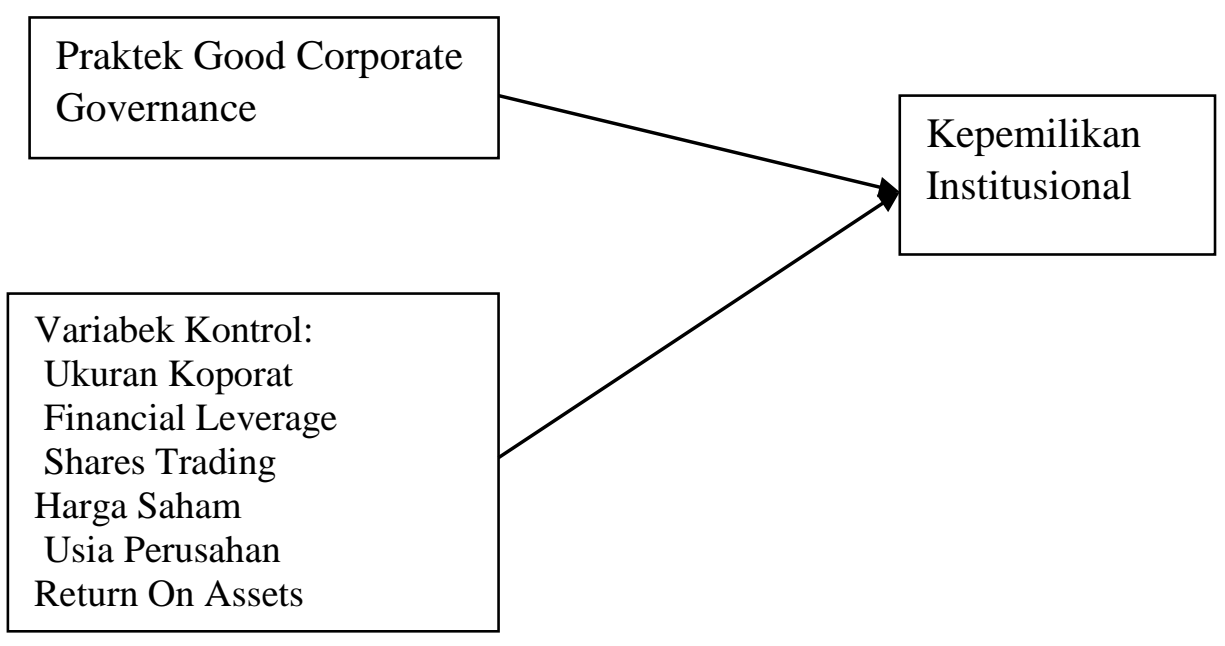

Pengembangan Hipotesis. Pengaruh praktektata kelola perusahaan terhadap kepemilikan institusional. Salah satu faktor yang dapat mempengaruhi kinerja perusahaan adalah kepemilikan institusional. Adanya kepemilikan institusional di suatu perusahaan akan mendorong peningkatan pengawasan agar lebih optimal terhadap kinerja 
manajemen, karena kepemilikan saham mewakili suatu sumber kekuasaan yang dapat digunakan untuk mendukung atau sebaliknya terhadap kinerja manajemen. Pengawasan yang dilakukan oleh investor institusional sangat bergantung pada besarnya investasi yang dilakukan.

Semakin besar kepemilikan institusi keuangan maka akan semakin besar kekuatan suara dan dorongan dari institusi keuangan tersebut untuk mengawasi manajemen dan akibatnya akan memberikan dorongan yang lebih besar untuk mengoptimalkan nilai perusahaan sehingga kinerja perusahaan akan meningkat. Investor institusional dapat menjadi sangat penting serta dapat digunakan untuk menyelaraskan kepentingan manajemen dengan pemegang saham.Hal ini disebabkan karena jika tingkat kepemilikan manajeral tinggi, dapat berdampak buruk terhadap perusahaan karena menimbulkan masalah pertahanan, yang berarti jika kepemilikan manajerial tinggi, para manajer memiliki memiliki posisi yang kuat untuk melakukan suatu kontrol terhadap perusahaan dan pihak pemegang saham eksternal akan mengalami kesulitan untuk mengendalikan tindakan para manajer tersebut.

Penelitian yang dilakukan oleh Bushee dan Noe (2000) menyatakan bahwa investor institusional lebih memilih perusahaan dengan peringkat pengungkapan yang lebih baik untuk mengurangi biaya monitoring.Sampai-sampai perusahaan yang memiliki struktur tata kelola yang lebih baik membutuhkan lebih sedikit pemantauan di luar, investor institusional cenderung lebih memilih perusahaan dengan mekanisme tata kelola yang lebih baik daripada mereka dengan mekanisme tata kelola yang buruk.Berdasarkan uraian tersebut maka hipotesis yang diajukan dalam penelitian ini adalah

$\mathrm{H}_{1}$ : Kualitas praktek tata kelola perusahaan berpengaruh positif terhadap keputusan pemilihan saham oleh investor institusional.

\section{METODE}

Sampel dan Data. Populasi dalam penelitian ini adalah seluruh perusahaan perbankan yang listing di Bursa Efek Indonesia periode tahun 2011-2013.Penelitian ini mengambil sampel pada perusahaan perbankan yang terdaftar di Bursa Efek Indonesi (BEI) yang beroperasi pada tahun 2011-2013 berjumlah 26 perusahaan dengan melakukan praktekcorporate governance. Metode pemilihan sampel dalam penelitian ini menggunakan purposive samplingataujudgmental sampling yaitu penarikan sampel secara purposif merupakan cara penarikan sample yang dilakukan memilih subjek berdasarkan kriteria spesifik yang ditetapkan peneliti.

Metode pengumpulan data pada penelitian ini adalah dengan metode dokumentasi, yaitu penggunaan data yang berasal dari dokumen-dokumen yang sudah ada. Hal ini dilakukan dengan cara melakukan penelusuran dan pencatatan informasi yang sudah ada pada data sekunder berupa laporan penerapan tata kelola perusahaan dan laporan tahunan perusahaan perbankan yang terdaftar di Bursa Efek Indonesia (BEI) periode 2011-2013.

Jenis data yang digunakan dalam penelitian ini adalah data sekunder.Data sekunder merupakan data yang sudah tersedia sehingga kita tinggal mencari dan mengumpulkan. Dalam penelitian ini, data sekunder yang dipakai adalah laporan tahunan dan laporan penerapan tata kelola perusahaan perusahaan Perbankan Indonesia sesuai dengan Peraturan Bank Indonesia Nomor 8/12/PBI/2006 tentang Perubahan atas Peraturan Bank Indonesia Nomor 8/4/PBI/2006 tentang Pelaksanaan Good Corporate Governance. 
Dalam penelitian ini, sumber data yang dipakai adalah skor praktek tata kelola perusahaan bank berdasarkan self-assessment pada implementasi GCG sesuai dengan aturan Bank Indonesia Nomor 8/14/PBI/2006.Laporan pelaksanaan tata kelolaperusahaan dan laporan tahunan yang diperoleh dari website perusahan-perusahan perbankan, terutama untuk data skor CG dan data laporan tahunan perusahaan pada tahun 2011-2013. Selain itu, dari Bursa Pojok BEI Universitas Kristen Duta Wacana Yogyakarta dan uraian artikel, jurnal, dokumen mengenai penerapan Good Corporate Governance pada perusahaan-perusahaan perbankan di Indonesia.

Definisi Operasional Variabel. Variabel Dependen. Variabel dependen atau terikat adalah variabel yang menjadi pusat atau inti dari sebuah penelitian yang diduga dipengaruhi oleh variabel independen. Variabel dependen dalam penelitian ini adalah Kepemilikan Institusional (Institutional Ownership) dilambangkan dengan IO.

Kepemilikan institusionaladalah penjumlahan prosentase saham perusahaan yang dimiliki oleh institusi atau lembaga (perusahaan perbankan, asuransi, dana pensiun, atau perusahaan lain). Variabel kepemilikan institusional diukur dengan prosentase jumlah saham yang dimiliki institusi lain di luar perusahaan minimal 10\% terhadap total saham perusahaan. Pengukuran variabel ini mengacu pada penelitian Claessens et al (2000) yang mengevaluasi struktur kepemilikan di 9 negara Asia termasuk di Indonesia.Rumus untuk kepemilikan institusional adalah sebagai berikut:

$$
\text { IO }=\frac{\text { Jumlah saham yang dimiliki oleh per institusi }}{\text { Jumlah seluruh saham perusahaan yang beredar }} \times 100 \%
$$

Variabel Independen. Dalam penelitian ini, variabel independen adalaha praktek good corporate governance. PraktekGood Corporate Governance diatur dalam Peraturan Bank Indonesia Nomor 8/14/PBI/2006, yang mewajibkan Bank untuk melakukan self-assesment GCG. Penilaian terhadap pelaksanaan prinsip-prinsip Good Corporate Governance, paling kurang harus diwujudkan dan difokuskan dalam 11 (sebelas) Faktor Penilaian GCG yang terdiri dari: pelaksanaan tugas dan tanggung jawab Dewan Komisaris; pelaksanaan tugas dan tanggung jawab Direksi; kelengkapan dan pelaksanaan tugas Komite; Penanganan benturan kepentingan; penerapan fungsi kepatuhan;penerapan fungsi audit intern;Penerapan fungsi audit ekstern; penerapan manajemen risiko termasuk sistem pengendalian intern; penyediaan dana kepada pihak terkait dan penyediaan dana besar; transparansi kondisi keuangan dan non keuangan Bank, laporan pelaksanaan Good Corporate Governance dan pelaporan internal; rencana strategis Bank.

Kertas Kerja Self Assessment Good Corporate Governance disusun per Faktor Penilaian Pelaksanaan Good Corporate Governance. Format Kertas Kerja Self Assessment tersebut, terdiri dari kolom: Tujuan, Kriteria/Indikator, Analisis Self Assessment, Kriteria Peringkat Faktor Penilaian Pelaksanaan Good Corporate Governance dan Kesimpulan. Setelah melakukan penilaian terhadap masing-masing Faktor, Bank membobot faktorfaktor tersebut. Nilai Akhir masing-masing Faktor diperoleh dengan mengalikan bobot persentase dengan hasil Peringkat dari masing-masing Faktor. Untuk mendapatkan Nilai Komposit, Bank harus menjumlahkan Nilai Akhir dari 11 ( sebelas) Faktor di atas.Sebagai langkah terakhir, Bank menetapkan Nilai Komposit Hasil Self Assessment Pelaksanaan Good Corporate Governance Bank, dengan menetapkan klasifikasi Peringkat Komposit, sebagaimanapada Tabel 1. 
Tabel 1. Nilai Komposit

\begin{tabular}{lcl}
\hline \multicolumn{1}{c}{ Nilai Komposite } & $\begin{array}{c}\text { Nilai Konversi } \\
\text { Komposit }\end{array}$ & Predikat Komposit \\
\hline Nilai Komposit $<1,5$ & 5 & Sangat Baik \\
$1,5 \leq$ Nilai komposite $<2,5$ & 4 & Baik \\
$2,5 \leq$ Nilai komposit $<3,5$ & 3 & Cukup Baik \\
$3,5 \leq$ Nilai Komposit $<4,5$ & 2 & Kurang Baik \\
$4,5 \leq$ Nilai Komposit $<5$ & 1 & Tidak Baik \\
\hline
\end{tabular}

PraktekGood Corporate Governance dihitung berdasarkan indeks komposit Corporate Governance Bank yang disediakan oleh Bank Indonesia, memiliki nilai rating berkisar 1-5.Nilai yang paling rendah dari indeks komposit menunjukan bahwa praktek tata kelola perusahaan yang lebih baik. Namun, untuk menghindari kesalahan interprestasi dari hipotesis, peneliti memodifikasi output dari indeks komposit menjadi nilai yang paling tinggi menunjukan bahwa praktek tata kelola perusahaan yang lebih baik.

Variabel Kontrol. Variabel kontrol adalah variabel yang dikendalikan atau dibuat konstan sehingga hubungan variabel bebas terhadap variabel terikat tidak dipengaruhi oleh faktor luar yang tidak diteliti.Penggunaan variabel kontrol ini sesuai dengan jurnal acuan penulis sesuai juga dari penelitian terdahulu yang dilakukan oleh Chung dan Zhang (2011).

Falkenstein (1996) dan Huang (2009) memperlihatkan bahwa institusi cenderung memilih perusahan dengan likuiditas pasar yang lebih tinggi. Chung dan Zhang (2011) menemukan bahwa perusahaan dengan struktur tata kelola yang lebih baik cenderung memiliki likuiditas pasar saham yang lebih tinggi. Akibatnya, hubungan antara kepemilikan institusional dan nilai tata kelola mungkin karena dengan likuiditas masingmasing korelasi.

Selain itu, penelitian sebelumnya mengidentifikasi sejumlah variabel yang mempengaruhi keputusan portofolio investor institusi. Gompers dan Metrick (2001) menemukan bahwa investor institusi lebih memilih saham dari perusahaan besar, sementara Grinstein dan Michaely (2005) memperlihatkan bahwa investor institusional lebih memilih perusahaan yang membayar dividen yang lebih kecil diantara perusahaan membayar dividen. Badrinath et al. (1996) memperlihatkan bahwa investor institusi lebih memilih perusahaan dengan karakteristik jaring pengaman, seperti perusahan yang susah lama didirikan, volatilitas return rendah, dan financial leverage rendah.Gompers et al. (2003) menunjukkan Bahwa perusahaan dengan hak pemegang saham yang kuat menunjukkan return saham yang lebih tinggi dan kinerja operasional yang lebih baik. Berdasarkan uraian diatas, setiap variabel yang dapat memengaruhi Kepemilikan Institusional dijadikan variable control. Yang menjadi variabel kontrol dalam penelitian ini adalah:

1. Ukuran Perusahaan (CSize) $=$ Log(Total Aset)

2. Financial Leverage $($ Leverage $)=\frac{\text { TotalHutang }}{\text { TotalAset }}$

3. Stock Prise (Price)

= Rata-rata harga saham

4. Firm Age (FirmAge)

$=$ Jumlah tahun sejak berdirinya perusahaan tersebut.

5. Return On Assets (ROA) $=\frac{\text { TotalAset }}{}$ 
Model Empiris. Hipotesis yang akan diuji dalam penelitian ini yaitu pengujian pengaruh Praktek Tata Kelola Perusahaan(Corporate Governance) terhadap Kepemilikan Institusional (Institusional Ownership). Model yang digunakan untuk menguji pengaruh variabel-variabel secara spesifik terhadap kepemilikan institusional dalam penelitian ini dinyatakan dalam persamaan regresi di bawah ini:

Model 1: Variabel Y dihitung dengan memasukan variabel independen dan variabel kontrol.

$$
Y=\alpha+B 1 \text { SC.CG }+ \text { CSize }+ \text { Leverage }+ \text { Turnover }+ \text { Price }+ \text { FirmAge }+R O A+e
$$

Model 2: Variabel Y dihitung menggunakan variabel kontrol dengan mengeluarkan variabel independen.

$Y=\alpha+$ CSize + Leverage + Turnover + Price + FirmAge $+R O A+e$

Model 3: Variabel Y dihitung menggunakan variabel independen dengan mengeluarkan variabel kontrol.

$$
Y=\alpha+B 1 S C \cdot C G+e
$$

Keterangan: $\mathrm{Y}=$ Institusional Ownership $\alpha=$ Konstanta; $\beta 1=$ Koefisien Regresi; SC.CG= Skor Tata Kelola (Corporate Governance); CSize = Ukuran Perusahaan; Leverage= Financial Leverage; Price $=$ Stock Price; FirmAge $=$ Firm Age ROA = Return On Assets $\mathrm{e}=$ Error Term

\section{HASIL DAN PEMBAHASAN}

Statistik Deskriptif. Statistik deskriptif dalam penelitian ini digunakan untuk memberikan informasi mengenai variabel-variabel penelitian seperti Kepemilikan Institusional (Institutional Ownership), Praktek Tata Kelola Perusahaan (Corporate Governance), Ukuran Perusahaan (Corporate Size), Financial Leverage, Stock Price, Firm Age, dan Return On Assets (ROA). Berdasarkan pengolahan data dengan menggunakan aplikasi SPSS 21.00 diperoleh data deskriptif penelitian, sebagai berikut:

Tabel 2. Data Deskriptif

\begin{tabular}{lrrrrr}
\hline \multicolumn{1}{c}{ Variable } & N & Minimum & Maximum & \multicolumn{1}{c}{ Mean } & \multicolumn{1}{c}{ Std. Deviation } \\
\hline IO & 78 & .11030 & 1.00000 & .6480923 & .24614662 \\
SC.CG & 78 & 1 & 4 & 3.38 & .707 \\
CSize & 78 & 6.31815 & 12.60699 & 8.0469619 & 1.29232457 \\
Leverage & 78 & .75164 & .93983 & .8810812 & .03591099 \\
Price & 78 & 50.00 & 10191.67 & 2103.4442 & 2578.14279 \\
FirmAge & 78 & 13 & 118 & 52.31 & 28.408 \\
ROA & 78 & -.078 & 23.107 & .87701 & 4.346352 \\
\hline
\end{tabular}

Tabel 2 menyajikan statistik deskriptif pada nilai kepemilikan institusional (IO), praktek tata kelola (SC.CG), dan variabel kontrol dari sampel penelitian untuk perusahaan 
perbankan yang terdaftar di Bursa Efek Indonesia (BEI) dengan jumlah data yang valid sebanyak 78. Kepemilikan Institusional (IO)mempunya nilai minimum 0,11030, nilai maksimum 1,00000 dan rata-rata kepemilikan institusional adalah 0,6480923. SC.CG menunjukkan skor tata kelola untuk setiap perusahaan dalam satu tahun tertentu.Praktek tata kelola perusahaan (corporate governance) mempunyai nilai minimum 1 atau dalam kategori tidak baik, nilai maksimum 4 atau dalam kategori baik dan rata-rata praktek tata kelola adalah 3,38. SC.CG dari 3,38, hasil ini menunjukan bahwa praktek CG rata-rata disektor perbankan berada dalam kategori baik. Ukuran perusahaan (CSize) mempunyai nilai minimum 6,31815, nilai maksimum 12,60699 dan rata-rata ukuran perusahaan adalah 8,04696. Financial Leverage (Leverage) mempunyai nilai minimum 0,75164, nilai maksimum 0,93983 dan rata-rata financial leverage adalah 0,88108. Stock Price (Price) mempunyai nilai minimum 50,00, nilai maksimum 10.191,67 dan rata-rata stock price adalah 2.103,44. Firm Age mempunyai nilai minimum 13, nilai maksimum 118 dan ratarata firm age adalah 52,31. Return On Assets (ROA) mempunyai nilai minimum negatif 0,078, nilai maksimum 23,107 dan rata-rata ROA adalah 0,87701.

Pengujian normalitas dalam penelitian ini dengan menggunakan one sample kolmogorov-smirnov test. Dalam uji one sample kolmogorov-smirnov test variabelvariabel yang mempunyai asymp. Sig (2-tailed) di bawah tingkat signifikan sebesar 0,05 maka diartikan bahwa variabel-variabel tersebut memiliki distribusi tidak normal dan sebaliknya (Ghozali, 2009). Hasil uji normalitas, hasilnya menunjukkan nilai Kolmogorov-Smirnov sebesar 0,696 dengan tingkat probabilitas signifikasi sebesar 0,718.Karena nilai Asymp. Sig. (-tailed) 0,711 lebih besar dari 0,05, maka disimpulkan bahwa data yang diuji berdistribusi normal. Maka model regresi yang digunakan memenuhi asumsi normalitas. Dalam penelitian ini digunakan uji asumsi klasik yang bertujuan untuk menentukan ketepatan model. Uji asumsi klasik yang akan digunakan dalam penelitian ini yaitu Uji Multikolinearitas, Uji Heterokedastisitas, dan Uji Autokorelasi.

Uji multikolinearitas bertujuan untuk menguji apakah dalam model regresi ditemukan adanya korelasi antara variabel bebas (Ghozali, 2009).Model regresi yang baik seharusnya tidak terjadi korelasi diantara variabel independen. Untuk mendeteksi ada atau tidaknya multikolinearitas, dapat dilihat dari nilai tolerance dan lawannya variance inflation factor (VIF). Tolerance mengukur variabilitas variabel independen yang terpilih yang tidak dijelaskan oleh variabel independen lainnya. Jadi nilai tolerance yang rendah sama dengan nilai VIF tinggi (karenaVIF=1/Tolerance). Nilai cutoff yang umum dipakai untuk menunjukan adanya multikolinearitas adalah nilai Tolerance $\leq 0,10$ atau sama dengan nilai VIF $\geq 10$. Hasil uji multikolinearitas, hasilnya menunjukkan bahwa variable praktek tata kelola memiliki nilai tolerance diatas 0,10dan nilaiVariance Inflation Factor (VIF) dibawah 10.Maka dapat disimpulkan bahwa tidak terjadi multikolinearitas antar variabel bebas dalam model regresi ini.

Pengujian Heterokedastisitas dalam penelitian ini menggunakan uji Park Gleyser dengan cara mengorelasikan nilai absolute residualnya dengan masing-masing variabel independen. Jika hasil nilai probabilitasnya memiliki nilai signifikansi $>$ nilai alpha-nya $(0,05)$, maka model tidak mengalami Heterokedastisitas. Hasil uji heterokedastisitas, hasilnya menunjukan bahwa korelasi antara praktek tata kelola dengan unstandardized residual berada pada nilai signifikansi 0,005 lebih kecil dari 0,05, maka ditarik kesimpulan bahwa model mengalami masalah heterokedastisitas. 
Dengan adanya masalah heterokedastisitas penulis telah melakukan penyembuhan dengan menggunakan Weighted Least Squares. Hasilnya menunjukan bahwa undstandardized coefficient berada pada nilai signifikansi 0,016 lebih kecil dari 0,05 maka ditarik kesimpulan bahwa model tetap mengalami masalah heterokedastisitas. Uji autokolerasi bertujuan untuk melihat ada tidaknya korelasi antara residual pada suatu pengamatan dengan pengamatan yang lain pada model. Dalam penelitian ini digunakan uji autokolerasi dengan menggunakan metode Durbin Watson.Nilai DW kemudian dibandingkan dengan nilai kritis Durbin-Watson untuk mengetahui signifikansinya.DW dikatakan tidak terjadi autokorelasi jika DW berada di antara DU sampai dengan 4DU.Hasil uji autokolerasi, hasilnya menunjukan bahwa nilai DW sebesar 1,967. Nilai ini akan dibandingkan dengan nilai tabel Durbon-Watson dengan signifikansi 5\%. Dari tabel DW diperoleh nilai batas atas (du) 1,6581. Karena nilai DW 1,967 berada diantara nilai batas atas (du) 1,6581 sampai dengan 4-du 2,3419, maka dapat disimpulkan bahwa data yang akan diolah tidak terdapat autokolerasi.

Uji Hipotesis Model 1. Uji hipotesis pada model regresi 1 dalam penelitian ini dengan memasukan variabel independen dan variabel kontrol.Tabel 3 menyajikan hasil pengujian hipotesis dengan menggunakan variabel independen dan variabel kontrol untuk menguji pengaruh praktek tata kelola perusahaan terhadap kepemilikan institusional. Hasil regresi menunjukan nilai koefisien variabel independen (SC.CG) sebesar 0,113 dan nilai signifikan $0,004<\alpha=0,05$. Hasil ini menunjukan bahwa praktek tata kelola perusahaan memiliki pengaruh signifikan terhadap kepemilikan institusional. Hasil regresi pada ukuran perusahaan (CSize)menunjukkan nilai koefisien0,062 dan nilai signifikan $0,004<\alpha=0,05$. Hasil ini menunjukkan bahwa ukuran perusahaan berpengaruh terhadap kepemilikan institusional.

Tabel 3. Hasil Model 1: Pratek Tata Kelola dan Variabel Kontrol

\begin{tabular}{|c|c|c|c|c|c|}
\hline \multirow[t]{2}{*}{ Variable } & \multicolumn{2}{|c|}{ Unstandardized Coefficients } & \multirow{2}{*}{$\begin{array}{c}\begin{array}{c}\text { Standardized } \\
\text { Coefficients }\end{array} \\
\text { Beta } \\
\end{array}$} & \multirow[t]{2}{*}{$\mathrm{t}$} & \multirow[t]{2}{*}{ Sig. } \\
\hline & $\mathrm{B}$ & Std. Error & & & \\
\hline (Constant) & .750 & .727 & & 1.032 & .306 \\
\hline SC.CG & .113 & .038 & .323 & 2.962 & .004 \\
\hline CSize & .062 & .021 & .328 & 3.009 & .004 \\
\hline Leverage & -1.052 & .762 & -.153 & -1.380 & .172 \\
\hline Price & $-3.066 \mathrm{E}-005$ & .000 & -.321 & -2.697 & .009 \\
\hline FirmAge & .000 & .001 & -.014 & -.131 & .896 \\
\hline ROA & .013 & .006 & .238 & 2.198 & .031 \\
\hline
\end{tabular}

a. Dependent Variable: IO

Hasil regresi pada financial leverage(Leverage) menunjukkan nilai koefisien negatif $-1,052$ dan nilai signifikan $0,172>\alpha=0,05$. Hasil ini menunjukkan bahwa financial leverage tidak berpengaruh terhadap kepemilikan institusional. Hasil regresi pada stock price(Price) menunjukkan nilai koefisien negatif -3,066E-005dan nilai signifikan $0,009<\alpha=0,05$. Hasil ini menunjukan bahwa stock price memiliki pengaruh negatif signifikan terhadap kepemilikan institusional. Hasil regresi pada FirmAge menunjukkan nilai koefisien0,000dan nilai signifikan $0,896>\alpha=0,05$. Hasil ini menunjukkan bahwa firm age tidak berpengaruh terhadap kepemilikan institusional. Hasil regresi pada ROA 
menunjukkan nilai koefisien 0,013 dan nilai signifikan $0,031<\alpha=0,05$. Hasil ini menunjukan bahwa ROA memiliki pengaruh terhadap kepemilikan institusional.

Uji Hipotesis Model 2. Uji hipotesis pada model regresi 2 dalam penelitian ini dengan menggunakan variabel kontrol tanpa variabel independen praktek tata kelola perusahaan.Tabel 4 menyajikan hasil pengujian hipotesis dengan menggunakan variabel kontrol tanpa variabel independen. Pengujian ini dilakukan untuk menguji apakah Ukuran Perusahaan, Financial Leverage, Stock Price, Firm Age, dan Return On Assets (ROA) berpengaruh terhadap Kepemilikan Institusional.

Tabel 4. Model 2: Variabel Kontrol

\begin{tabular}{|c|c|c|c|c|c|}
\hline \multirow{2}{*}{ Variable } & \multicolumn{2}{|c|}{ Unstandardized Coefficients } & \multirow{2}{*}{$\begin{array}{c}\begin{array}{c}\text { Standardized } \\
\text { Coefficients }\end{array} \\
\text { Beta }\end{array}$} & \multirow{2}{*}{$\mathrm{t}$} & \multirow{2}{*}{ Sig. } \\
\hline & $\mathrm{B}$ & Std. Error & & & \\
\hline (Constant) & 1.174 & .750 & & 1.565 & .122 \\
\hline CSize & .057 & .022 & .301 & 2.636 & .010 \\
\hline Leverage & -1.084 & .802 & -.158 & -1.352 & .181 \\
\hline Price & $-1.986 \mathrm{E}-005$ & .000 & -.208 & -1.752 & .084 \\
\hline FirmAge & $-7.916 \mathrm{E}-005$ & .001 & -.009 & -.083 & .934 \\
\hline ROA & .015 & .006 & .265 & 2.337 & .022 \\
\hline
\end{tabular}

Dependent Variable: IO

Hasil regresi pada ukuran perusahaan (CSize) menunjukkan nilai koefisien0,057 dan nilai signifikan $0,010<\alpha=0,05$. Hasil ini menunjukkan bahwa ukuran perusahaan berpengaruh terhadap kepemilikan institusional. Hasil regresi pada financial leverage(leverage) menunjukkan nilai koefisien negatif -1,084dan nilai signifikan $0,181>\alpha=0,05$. Hasil ini menunjukkan bahwa financial leverage tidak berpengaruh terhadap kepemilikan institusional.Hasil regresi pada stock price(Price) menunjukkan nilai koefisien negatif -1,986E-005dan nilai signifikan $0,084>\alpha=0,05$. Hasil ini menunjukan bahwa stock price tidak berpengaruh terhadap kepemilikan institusional. Hasil regresi pada FirmAge menunjukkan nilai koefisien negatif -7,916E-005dan nilai signifikan $0,934>\alpha=0,05$. Hasil ini menunjukkan bahwa firm age tidak berpengaruh terhadap kepemilikan institusional. Hasil regresi pada ROA menunjukkan nilai koefisien 0,015 dan nilai signifikan $0,022<\alpha=0,05$. Hasil ini menunjukan bahwa ROA memiliki pengaruh terhadap kepemilikan institusional.

Uji Hipotesis Model 3. Uji Hipotesis model 3 dengan memasukan variabel independen praktek tata kelola perusahaan (SC.CR) dan mengeluarkan variabel kontrol.

Tabel 5. Model 3: Praktek Tata kelola dan Tanpa Variabel Kontrol

\begin{tabular}{|c|c|c|c|c|c|}
\hline \multirow[t]{2}{*}{ Variable } & \multicolumn{2}{|c|}{ Unstandardized Coefficients } & $\begin{array}{l}\text { Standardized } \\
\text { Coefficients }\end{array}$ & \multirow[t]{2}{*}{$\mathrm{t}$} & \multirow[t]{2}{*}{ Sig. } \\
\hline & B & Std. Error & Beta & & \\
\hline (Constant) & .357 & .134 & & 2.669 & .009 \\
\hline SC.CG & .086 & .039 & .247 & 2.220 & .029 \\
\hline
\end{tabular}

Dependent Variable: IO 
Pengujian hipotesis dalam penelitian ini adalah menguji pengaruh praktek tata kelola perusahaan terhadap kepemilikan institusional. Tabel 5 menyajikan hasil regresi yang menunjukan nilai koefisien praktek tata kelola perusahaan (SC.CR) adalah 0,086 dan nilai signifikan $0,029<\alpha=0,05$. Hasilnya menunjukan bahwa praktek tata kelola perusahaan berpengaruh positif terhadap kepemilikan institusional.Dengan demikian penelitian ini mendukung penelitian terdahulu, Chung dan Zhang (2011).

Pembahasan. Penelitian ini bertujuan menguji praktektata kelola perusahaan terhadap kepemilikaan institusional dengan mempertimbangkan beberapa variabel kontrol.Hasil Penelitian mengungkapkan bahwa variabel kontrol berfungsi sebagai variabel yang konstan yang berfungsi sebagai variabel yang mengontrol variabel dependen dan variabel independen. Hasil model regresi 1 dan model regresi 2 pada variabel kontrol yaitu Ukuran Perusahaan, Financial Leverage, Stock Price, Firm Age, dan Return On Assets (ROA) menunjukan bahwa ada variabel kontrol yang berpengaruh terhadap kepemilikan institusional. Dalam model regresi 1 dengan menggunakan variabel independen dan variabel kontrol, hasilnya menunjukan ukuran perusahaan, stock price, dan ROA berpengaruh terhadap kepemilikan institusional.Dalam model 2 dengan mengeluarkan variabel independen, hasilnya menunjukan ukuran perusahaan dan ROA berpengaruh terhadap kepemilikan institusional. Hal ini menunjukan bahwa investor institusional tidak hanya memilih saham dengan praktek tata kelola perusahaan yang baik, namun investor institusional juga memilih saham perusahaan dari perusahaan yang besar (Gompers dan Metrick, 2001), perusahaan dengan return yang tinggi dan operasional yang baik (Gompers et al., 2003) serta perusahaan yang memiliki harga saham yang tinggi.

Hasil regresi pada praktek tata kelola perusahaanmenunjukan berpengaruh positif terhadap kepemilikan institusional.Hasil ini menunjukan bahwa investor institusional memilih saham perusahaan dengan praktek tata kelola perusahaan yang baik.Penelitian ini mendukung penelitian dari Chung dan Zhang (2011), yang hasilnya menunjukkan bahwapraktek CG berpengaruh positif terhadap kepemilikan institusional.Saham perusahaan yang dipegang oleh investor institusional meningkat dengan kualitas struktur tata kelola yang baik. Hasil ini konsisten dengan dugaan bahwa investor institusional cenderung ke saham perusahaan dengan struktur tata kelola yang baik untuk memenuhi tanggung jawab fidusia dan juga untuk meminimalkan biaya pemantauan dan biaya keluar. Dengan demikian, penelitian ini mendukung hipotesis bahwa kualitas praktek tata kelola perusahaan berpengaruh positif terhadap keputusan pemilihan saham oleh investor institusional.

Hasil ini juga menunjukkan bahwa perusahaan-perusahaan perbankan yang terdaftar di Bursa Efek Indonesia (BEI) sudah menerapkan praktek tata kelola perusahaan yang baik sesuai dengan peraturan Bank Indonesia. Dalam kajian ini ditunjukan rata-rata praktek tata kelola dari 26 perusahaan sampel penelitian yaitu bank yang terdaftar di Bursa Efek Indonesia adalah 3,38, hasil ini menunjukan bahwa praktek CG rata-rata disektor perbankan berada dalam kategori baik. Dimana Dewan komisaris melalui perannya dalam melaksanakan fungsinya sesuai Anggaran Dasar yang merujuk kepada Undang-Undang Perseroan Terbatas, ketentuan Bank Indonesia, dan Lembaga Keuangan (Bapepam dan LK).Dalam memenuhi tugas dan tanggung jawabnya, Dewan Komisaris bertindak secara independen.Dewan Direksi merupakan organ Perseroan yang berwenang dan bertanggungjawab penuh atas pengurusan Perseroan untuk kepentingan perseroan, sesuai dengan maksud dan tujuan perseroan serta mewakili perseroan, baik didalam maupun diluar pengadilan sesuai dengan anggaran dasar. Anggota Direksi perusahaan- 
perusahaan perbankan telah memiliki integritas keuangan yang tinggi, kompetensi, reputasi dan pengalaman, serta berbagai keahlian, dan semuanya telah lulus uji kemampuan dan kepatutan Bank Indonesia. Komite Audit perusahaan perbankan telah melaksanakan fungsi dan tanggung jawab dengan baik, maka hal ini mendorong terwujudnya prinsip-prinsip GCG yang mendorong perusahan untuk selalu bertanggung jawab kepada kepentingan seluruh stakeholders.Dengan demikian, penelitian ini juga mendukung upaya Bank Indonesia dalam meningkatkan praktek tata kelola perusahaan didalam sektor perbankan.

\section{PENUTUP}

Kesimpulan. Penelitian ini menganalisis pengaruh praktek tata kelola perusahaan terhadap kepemilikan institusional dengan dugaan bahwa investor insitusional cenderung lebih memilih saham perusahaan yang memiliki tata kelola perusahaan yang baik dengan variabel kontrol Ukuran Perusahaan, Financial Leverage, Stock Price, Firm Age, dan Return On Assets (ROA), pada perusahaan perbankan yang terdaftar di Bursa Efek Indonesia pada tahun 2011-2013.

Menggunakan indeks komposit Corporate Governance (CG) sesuai dengan ketentuan Bank Indonesia Nomor 8/14/PBI dan menggunakan nilai konversi komposit CG,menemukan bahwa praktek tata kelola perusahaan berpengaruh positif terhadap kepemilikan institusional. Hasil ini mendukung penelitian dari Chung dan Zhang (2011), yang hasilnya menunjukkan bahwasaham perusahaan yang dipegang oleh investor institusional meningkat dengan kualitas struktur tata kelolanya. Hal ini menunjukan bahwa investor institusional di Indonesia menyadari mekanismecorporate governance dalam memilih saham perusahaan.

Keterbatasan Penelitian. Dalam penelitian ini memiliki keterbatasan antara lain penggunaan periode penelitian yang pendek yaitu, hanya 3 tahun dengan sampel yang hanya 26 perusahaan.Dalam penelitian ini variabel independen yaitu praktek tata kelola (CG) diukur menggunakan skor komposit CG sesuai ketentuan Bank Indonesia Nomor 8/14/PBI, namun penulis hanya menemukan data skor CG dalam laporan penerapan praktek tata kelola perusahaan maupun laporan tahunan disebagian perusahaan perbankan yang terdaftar di Bursa Efek Indonesia (BEI).

Saran. Bagi Akademisi. Penelitian ini diharapkan dapat melengkapi penelitian-penelitian terdahulusehubungan dengan tata kelola perusahaan dan investor institusional, serta dapat menambah referensi atau pengetahuan tentang tata kelola perusahaan dan investor institusional dalam suatu karya penelitian selanjutnya dengan menambah variabel independen dan variabel kontrol yang lain. Dalam penelitian selanjutnya dianjurkan dapat dilakukan dengan melihat pengaruh ukuran perusahaan, stock price, dan ROA terhadap kepemilikan institusional dan hubungan antara corporate governance dan kepemilikan institusional di sektor lain.

Bagi Perusahaan. Penelitian ini diharapkan dapat menjadi masukan bagi perusahaan perbankan di Indonesia untuk lebih meningkatkan praktekgood corporate governance dengan memperhatikan 11 (sebelas) faktor penilaian GCGdalam mengelola perusahaan sesuai dengan peraturan Bank Indonesia, karena dengan penerapan GCG yang baik dapat menarik minat investor institusional untuk memilih saham perusahaan.

Bagi Investor Institusional. Penelitian ini diharapkan dapat menjadi masukan bagi 
investor institusional dalam memilih saham perusahaan.Investor dapat melihat perusahaan yang sudah menerapkan praktekcorporate governance menjadi pertimbangan saat mengambil keputusan investasi karena perusahaan dengan tata kelola yang baik cenderung membutuhkan lebih sedikit pemantauan dan memiliki likuiditas pasar saham yang lebih tinggi.

\section{DAFTAR RUJUKAN}

Badrinath, S. G.; J. R. Kale; and H. E. Ryan, Jr. (1996) “Characteristics of Common Stock Holdings ofInsurance Companies”. Journal of Risk and Insurance, 63: 49-76.

Bangun, P. dan Jeffry, (2008) "Pengaruh Good Corporate Governance dan Kinerja Keuangan Terhadap Harga Saham”. Jurnal Akuntansi, 8(1): 85-106

Beasley, M.S. (1996) "An empirical analysis of the relation between the boards of directors composition and financial statement fraud”. The Accounting Review, 71: 443-465.

Boediono, Gideon Setyo B. (2005) Kualitas Laba: Studi Pengaruh Mekanisme Corporate Governance dan Dampak Manajemen Laba dengan Menggunakan Analisis Jalur. Simposium Nasional Akuntansi VIII, Solo, 15-16 September

Bushee, B. J., and C. F. Noe. (2000) "Corporate Disclosure Practices, Institutional Investors, and Stock ReturnVolatility”. Journal of Accounting Research, 38, 171202.

Chung, K. H.dan Zhang H. (2011) “Corporate Governance and Institusional Ownership”. Journal of Financial and Quantitative Analysis, 46 (1): 247-273.

Daniri, M. A. (2005) Good Corporate Governance. Ray Indonesia, Jakarta

Egon Zehnder International. (2000) Corporate Governance and the Role of The Board of Directors.

Falkenstein, E. G. (1996) "Preferences for Stock Characteristics as Revealed by Mutual Fund PortfolioHoldings”. Journal of Finance, 5: 111-135.

Gompers, P.; J. Ishii; and A. Metrick. (2003) “Corporate Governance and Equity Prices”. Quarterly Journalof Economics, 118, 107-155.

Gompers, P. A., and A. Metrick.(2001) "Institutional Investors and Equity Prices". Quarterly Journal of Economics, 116, 229-259.

Grinstein, Y., and Michaely, R. (2005) "Institutional Holdings and Payout Policy". Journal of Finance,60, 1389-1426.

Jensen, M. C., and W. H. Meckling. (1976) "Theory of the Firm: Managerial Behavior, Agency Cost andOwnership Structure”. Journal of Financial Economics, 3, 305360.

Hamdan, A. M., and Al-Sartawi, A.M., (2013) "Corporate Governance and Institutional Ownership: Evidence from Kuwait's Financial Sector”. Jordan Journal of Business Administration, 9:(1)

Huang, J. (2007) Dynamic Liquidity Preferences of Mutual Funds.Working Paper, Boston College.

Ibrahim, M. (2007) "Pengaruh Sturktur Internal Governance terhadap Earning Manajemen”. Skripsi. Universitas Diponegoro. Semaran

Isnanta, (20080 Pengaruh Corporate Governance dan Struktur Kepemilikan Terhadap Manajemen Laba dan Kinerja. UII: Yogyakarta 
Lastanti, H. S., (2004) Hubungan Struktur Corporate Governance Dengan Kinerja Perusahaan dan Reaksi Pasar, Konferensi Nasional Akuntansi.

McKinsey and Company. (2002) Global Investor Opinion Survey: Key Findings.” http://www.mckinsey.com/clientservice/organizationleadership/service/corpgoverna nce/pdf/globalinvestoropinionsurvey2002.pdf

Parrino, R.; R. W. Sias; and L. T. Starks. (2003) "Voting with Their Feet: Institutional Ownership Changesaround Forced CEO Turnover". Journal of Financial Economics, 68, 3-46.

Peraturan Bank Indonesia Nomor 8/12/PBI/2006 tentang Perubahan atas Peraturan Bank Indonesia Nomor 8/4/PBI/2006 tentang Pelaksanaan Good Corporate Governance.

Priambodo, R. E. A dan E. Suprayitno, (2007) 'Penerapan Good Corporate Governance Sebagai Landasan Kinerja Perbankan Nasional”, Usahawan, No. 05, Th. XXXVI.

Shleifer, A. and Vishny, R.W. (1997) “A Survey of Corporate Governance”. Journal of Finance, 52(2): 737-783.

Triyono. (2014) Pengaruh Kualitas Corporate Governance, Kepemilikan Institusional, Terhadap Kinerja Dan Risiko Perusahaan.Universitas Muhammadiyah Surakarta.

Ujiyantho dan Pramuka, (2007) Mekanisme Corporate Governance, Manajemen Laba dan Kinerja Keuangan (Studi Pada Perusahaan go publik Sektor Manufaktur), Jurnal Simposium Nasional Akuntansi X. Makasar

Utama, C.A. dan Musa H. (2011) "The Causality between Corporate Governance Practice and Bank Performance”. Gadjah Mada International Journal of Business, 13 (3), $227-247$.

Herawaty, V. (2008) "Peran Praktek Corporate Governance Sebagai Moderating Variable dari Pengaruh Earnings Management Terhadap Nilai Perusahaan”. Jurnal Akuntansi dan Keuangan, 10 (2): 97-108 